Chirurgia (2020) 115: 23-38

No. 1, January - February

Copyright $@$ Celsius

http://dx.doi.org/10.21614/chirurgia.115.1.23

\title{
Analysis of Prognostic Factors in Complicated Colorectal Cancer Operated in Emergency
}

\author{
Georgiana Bianca Constantin', Dorel Firescu ${ }^{2,3}$, Dragoș Voicu' ${ }^{2}$ Bogdan Ștefănescu ${ }^{2,3}$, Raul Mihailov', \\ Cristina Șerban ${ }^{2,3}$, Sorin Berbece ${ }^{2}$, Eugenia Panaitescu' ${ }^{1}$, Rodica Bîrlăa, ${ }^{1,4}$ Cristian Marica ${ }^{1,4}$, Silviu Constantinoiu ${ }^{1,4}$ \\ ${ }^{1}$ Carol Davila University of Medicine and Pharmacy, Bucharest, Romania \\ ${ }^{2}$ Dunarea de Jos University, Faculty of Medicine and Pharmacy, Galati, Romania \\ ${ }^{3}$ Clinical Emergency County Hospital Sf. Ap. Andrei, Galati, Romania \\ ${ }^{4}$ General and Esophageal Surgery Department, Center of Excellence in Esophageal Surgery, Saint Mary Clinical Hospital, Bucharest, Romania
}

Corresponding author:

Rodica Birla, MD

General and Esophageal Surgery

Department, Center of Excellence

in Esophageal Surgery, Sf. Maria

Clinical Hospital, Bucharest, Romania

E-mail: birlarodica@ahoo.com
Received: 07.01.2020

Accepted: 15.02 .2020

\section{Rezumat}

Analiza factorilor prognostici în cancerul colorectal complicat operat în urgență

Introducere: În anul 2018 cancerul de colon se afla pe locul al 5-lea ca mortalitate prin cancer, iar cancerul rectal pe locul al 10-lea. Supraviețuirea la distanță a bolnavilor cu cancer colorectal operat în urgență, rămâne nesatisfăcătoare, decesul fiind datorat recidivelor locale şi a metastazelor.

Scopul: Evaluarea unor corelații ale supraviețuirii globale cu caracteristici clinico-paraclinice, tumorale sau de tratament pentru identificarea factorilor de prognostic la pacienții cu cancer colorectal operat în urgentă.

Material şi Metode: Am efectuat o analiză retrospectivă la 431 pacienți cu cancer colorectal operat în urgență în perioada 20082017, cu excluderea celor 40 de pacienți cu decese postoperatorii, cu o perioadă de urmărire de cel puțin un an. S-au efectuat corelații ale unor caracteristici clinico-paraclinice, tumorale sau de tratament cu supraviețuirea globală.

Rezultate: În analiza statistic univariată de supraviețuire, se obține o asociere semnificativă statistic cuः vârsta > 61 ani (p_value $=0.000049)$, antecedentele chirurgicale abdominal ( $\mathrm{p}_{-}$value $=$ $0,031725)$, bolile cardiace (p_value $=0,000007)$, fibrilația atrială (p_value $=0,007496)$, diagnosticul la internare (p_value $=$ $0,034352)$, caşexia ( $\mathrm{p}$ _value $=0,000000)$, oligoanuria ( $\mathrm{p}$ _value $=$ $0,000000)$, anemia (p_value $=0,000006)$ dezechilibrul hidro-

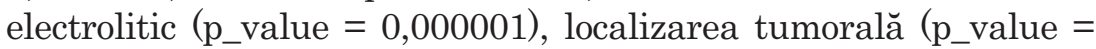


0,000030 ), invazia în organele vecine ( $\mathrm{p}$-value $=0,000000$ ), aspectul de pelvis înghețat ( $\mathrm{p}$-value $=$ $0,000000)$, carcinomatoza peritoneală (p_value $=0,000000)$, metastazele hepatice ( $\left.p_{\text {_value }}=0,000000\right)$, tipul de interventie chirurgicală $\left(\mathrm{p} \_\right.$value $\left.=0,000000\right)$, limfodisecția ( $\mathrm{p}$-value $=$ $0,000001$ ), biopsia hepatică (p_value $=0,043483)$, reintegrarea tranzitului intestinal (p_value $=$ 0,000000 ), interventiile seriate ( $\mathrm{p}$-value $=0,000000$ ), $\mathrm{pTNM}$ ( $\mathrm{p}$-value $=0,000000$ ), gradingul (p_value $=0,007069)$. Analiza de regresie multivariată Cox a arătat că: vârsta $>61$ ani $-\mathrm{HR}=1.026$, $95 \% \mathrm{CI}(1.012$, 1.039) (p_value $=0.000139)$, caşexia $-\mathrm{HR}=1.358,95 \% \mathrm{CI}(1.046,1.764)$ ( $\mathrm{p} \_$value $=$ $0,021617)$, carcinomatoza peritoneală $-\mathrm{HR}=2.346,95 \% \mathrm{CI}(1.163,4.732)\left(\mathrm{p} \_\right.$value $\left.=0,017253\right)$, stadiul bolii $-\mathrm{HR}=36.745,95 \% \mathrm{CI}=(14.778,91.366)\left(\mathrm{p}_{\text {_ }}\right.$ value $\left.=0,000000\right)$, tipul de intervenție $-\mathrm{HR}=$ $0.187,95 \% \mathrm{CI}(0.045,0.779)\left(\mathrm{p}_{-}\right.$value $\left.=0,021281\right)$ şi intervențiile seriate $-\mathrm{HR}=0.282,95 \%$ $\mathrm{CI}(0.144,0.551)\left(\mathrm{p}_{-}\right.$value $\left.=000213\right)$ sunt factori de prognostic independenți.

Concluzii: Factorii de prognostic pentru bolnavii cu cancere colorectale operate în urgență sunt: vârsta $>61$ ani, prezența antecedentelor chirurgicale abdominale şi a tarelor cardiace asociate, în special a fibrilației atriale, diagnosticul de iminență de perforație diastatică, caşexia, oligoanuria, anemia şi dezechilibrul hidro-electrolitic prezente la internare, tumorile rectale, invazia tumorală în organe vecine, aspectul de "pelvis înghețat", prezența metastazelor hepatice sau a carcinomatozei peritoneale, tumorile nediferențiate, stadiul III sau IV, practicarea unei derivații interne sau neefectuarea limfodisectiei. Vârsta peste 61 de ani, caşexia, precum şi carcinomatoza peritoneală sunt factori de risc independenți, iar, operația Hartmann şi intervențiile seriate sunt factori de protecție independenți.

Cuvinte cheie: cancer colorectal, factori de pronostic, urgență, tratament chirurgical

\section{Abstract}

Introduction: In 2018, the colon cancer was the $5^{\text {th }}$ type of neoplasia regarding the cancer mortality and the rectal cancer was the $10^{\text {th }}$. The survival of patients with colorectal cancer operated in emergency still remains unsatisfactory, the death being due to local recurrences and to metastases. The aim of this study is to evaluate some correlations of overall survival with clinic and paraclinic features, tumor or treatment characteristics in order to identify prognostic factors, for cases with colorectal tumors that underwent emergency surgery.

Material and Methods: We performed a retrospective analysis on 431 patients with colorectal cancer operated in emergency between 2008-2017, excluding 40 patients with postoperative deaths, with a follow-up period of at least one year. There were correlations of some clinic and paraclinic features, tumor or treatment characteristics with the overall survival.

Results: In the univariate statistical survival analysis, a statistically significant association was obtained with: the age $>61$ years $\left(\mathrm{p} \_\right.$value $\left.=0.000049\right)$, abdominal surgical history ( $\mathrm{p}$-value $=$ $0.031725)$, heart disease $\left(\mathrm{p} \_\right.$value $\left.=0.000007\right)$, atrial fibrillation $\left(\mathrm{p} \_\right.$value $\left.=0.007496\right)$, preoperative diagnosis $\left(p_{\text {_value }}=0.034352\right)$, cachexia $\left(p_{\text {_value }}=0.000000\right)$, oliguria $\left(\mathrm{p}_{\text {_value }}=0.000000\right)$, anemia (p_value $=0.000006)$ hydro-electrolytic disorders $\left(p_{-}\right.$value $\left.=0.000001\right)$, tumor localization (p_value $=0.000030)$, invasion into other organs ( $p_{\text {_value }}=0.000000$ ), appearance of "frozen pelvis" $\left(p \_v a l u e=0.000000\right)$, peritoneal carcinomatosis $\left(p \_v a l u e=0.000000\right)$, liver metastases $\left(p \_v a l u e=\right.$ $0.000000)$, type of surgery ( $p_{-}$value $\left.=0.000000\right)$, lymph node dissection ( $p_{-}$value $\left.=0.000001\right)$, liver biopsy $\left(p \_v a l u e=0.043483\right)$, stoma reversal $\left(p_{-}\right.$value $\left.=0.000000\right)$, serial interventions $\left(p \_v a l u e=\right.$ $0.000000)$, $p$ TNM ( $\left.p \_v a l u e=0.000000\right)$, tumor grading $\left(p \_v a l u e=0.007069\right)$. The Cox multivariate regression analysis revealed that: the age $>61$ years $-\mathrm{HR}=1,026,95 \% \mathrm{CI}(1,012,1,039)$ ( $\mathrm{p}$ value $=$ $0.000139)$, cachexia $-\mathrm{HR}=1,358,95 \%$ CI $(1,046,1,764)$ ( $\mathrm{p}$ value $=0.021617)$, peritoneal carcinomatosis $-\mathrm{HR}=2.346,95 \% \mathrm{CI}(1.163,4.732)\left(\mathrm{p} \_\right.$value $\left.=0.017253\right)$, disease stage $-\mathrm{HR}=36.745,95 \%$ CI $(14.778,91.366)\left(p_{-}\right.$value $\left.=0.000000\right)$, intervention type $-\mathrm{HR}=0.187,95 \%$ CI $(0.045,0.779)$ 
$\left(p_{\text {_ value }}=0.021281\right)$ and serial interventions $-\mathrm{HR}=0.282,95 \% \mathrm{CI}(0.144 .0 .551)\left(\mathrm{p}_{\text {_ value }}=000213\right)$ are independent prognostic factors.

Conclusions: The prognostic factors for patients with colorectal cancers operated in emergency are: the age $>61$, the presence of abdominal surgical history and associated cardiac conditions, especially atrial fibrillation, diagnosis of diastatic perforation imminence, cachexia, oliguria, hydro-electrolytic disorders at admission, rectal tumors, tumor invasion in other organs, the appearance of "frozen pelvis", the presence of liver metastases or peritoneal carcinomatosis, undifferentiated tumors, stage IV, practicing an internal derivation or not performing lymph node dissection. The age over 61, cachexia, as well as peritoneal carcinomatosis, stage III or IV are independent risk factors the Hartmann procedure and the serial interventions are independent protective factors.

Key words: colorectal cancer, prognostic factors, emergency, surgical treatment

\section{Introduction}

According to GLOBOCAN data, in 2012 there were 1.36 million newly diagnosed cases and 700,000 deaths caused by colorectal cancer (1). The recent GLOBOCAN 2018 analysis ranks the colon cancer in the $5^{\text {th }}$ place as cancer mortality, with 551,000 deaths and the rectal cancer in the $10^{\text {th }}$ place, with 300,000 deaths (2).

Although many therapeutic strategies have been developed in the last decades, the long-term survival of patients with colorectal cancer, especially those admitted in emergency with complicated tumors, remains unsatisfactory, due to local recurrences and metastases (3). According to the recent EUROCARE 5 analysis, the colorectal cancer had a minimal increase in 5-years survival over time (4).

In the emergency surgery conditions, it is considered that only about half of the patients can benefit from gestures with curative intent, the morbidity and the mortality in these cases being evidently higher compared to the elective interventions. Even when performing surgery with curative intent, the 5 -year survival of these patients rarely exceeds $30 \%$ (5).

The factors that influence the survival of patients with colorectal cancer, operated in emergency, are: age, biological status upon admission, symptomatology, tumor localiza- tion, invasion in other organs, presence of secondary disseminations, type of surgical intervention, need for re-interventions, complications after surgery, histological type, tumor grading and staging $(6,7)$.

In a 2012 guide from the European Society of Medical Oncology, the colorectal cancer occlusion and perforation are mentioned as being associated with poor prognosis and short-term survival in association with primary T4 tumors, incomplete lymph node dissection, invasion of lymphatic vessels and perineural invasion (8).

The 5-years survival of patients with colorectal cancer in advanced stages was evaluated for elective operations: for stage II- $87 \%-50 \%$, for stage III- $85-13 \%$ and for stage IV- $12 \%$ (9-11).The overall survival at 5 years for colorectal cancer patients operated in emergency has been evaluated in few studies and it is around 39\% (12).

\section{Patients and Methods}

We retrospectively analyzed the data of 431 patients admitted and operated for complicated colorectal cancers in the Surgery II clinic of the "Sf. Ap. Andrei " from Galati, between 20082017. For this study, we excluded the 40 postoperative deaths, leaving a group of 391 patients, for whom we performed the survival analysis. There were followed both the postoperative evolution and the re-admissions in 
the case of those with serial interventions, the controls of those operated during 2012-2017 and the number of survivors using the patient identification data in the Hipocrate/SIUI medical information system.

As prognostic factors of complicated colorectal cancer, epidemiological, clinico-paraclinical, therapeutic and tumor factors were analyzed. The following epidemiological and clinical factors were analyzed: age, sex, area, abdominal surgical history, comorbidities, preoperative diagnosis. We analyzed the following paraclinical factors: the values of hemoglobin, hematocrit, leukocytes, platelets and ionograms at admission. Among the therapeutic factors, we analyzed: tumor localization, invasion into other organs, intraoperative appearance of "frozen pelvis", presence of hepatic metastases and peritoneal carcinomatosis, type of surgery performed in emergency, lymphodissection, liver biopsy, stoma reversal of Hartmann procedures. The tumor factors analyzed were: pTNM stage, tumor grading and presence of mucus component.

\section{Study Design}

The patients included in this study were those with long-term survival, retrospectively analyzed. Epidemiological, clinic, pathologic, therapeutic and tumor characteristics were evaluated in the survival analysis.

\section{Statistical Analysis}

The survival analysis was performed from the time of diagnosis to the time of patients' death or until stopping the follow-up in the study (01.10.2019). As prognostic factors, survival curves were analyzed, using Kaplan-Meier method and the statistical significance analysis was performed with Log Rank (Mantel-Cox) and Breslow (Generalized Wilcoxon) tests. The mean and median survival time were calculated for survival estimation at $6,12,18,24,48$ and 60 months.

To identify potential prognostic factors, survival curves were analyzed, using the
Kaplan-Meier method, and statistical significance analysis was performed with Log Rank (Mantel-Cox) and Breslow (Generalized Wilcoxon) tests. Survival and median survival were calculated and survival was estimated at $6,12,18,24,48$ and 60 months. For the verification of the obtained results, the analysis of the proportional risk ratio Univariate Cox (HR) was performed, and for the statistical significance comparison we used the sigp-value test with $95.0 \%$ CI. The analysis of the Cox multivariate proportional risk ratio (HR) was performed to evaluate potential independent prognostic factors by introducing only those statistically significant variables detected in the univariate analysis. The accuracy of the prognostic factors was analyzed by evaluating the sensitivity and specificity of these markers, after establishing the cut off values, using the ROC curves.

Statistical analysis was performed using SPSS software (version 23.0). Statistical conclusions were formulated using as a statistically significant difference value $p<0.05$ for all calculations performed.

\section{Results}

Until the end of this study (01.10.2019), there were $379(87.93 \%)$ deaths and 12 survivors $(2.79 \%)$. The average survival was 19.81 months and the 5-year survival was $3.1 \%$.

We couldn't identify statistical relevance for survival in terms of the involvement of epidemiological factors: sex (p_value $=0.348363)$, provenance environment (p_value $=0.465583$ ), hereditary-collateral antecedents (p_value = 0.857916), colic resections antecedents (p_value $=0.186804)$, liver cirrhosis $\left(p \_v a l u e=0.106936\right)$, pre-existing colon pathology (p_value = 0.571957), clinic and paraclinic factors: presence of abdominal pain at admission (p_value = $0.748323)$, presence of intestinal transit disorders (p_value $=0.834845)$, severe anemia with preoperative transfusion ( $p \_v a l u e=0.921275$ ), leukocytosis (p_value $=0.099868)$, thrombocytopenia (p_value $=0.106936$ ), operative factors: type of parietoraphy (p_value = 0.103058), postoperative complications (p_value 
$=0.774076)$, reoperations ( $\mathrm{p}$-value $=0.768389$ ), tumor factors: pathological type (p_value = 0.172264 ), presence of tumors with mucus component (p_value $=0,270$ 325).

Comparing the survival in patients who had increased values of the age with those who had low values of age, the risk of death was calculated in the case of the presence of increased values of the age- $\mathrm{HR}=1,032,95 \% \mathrm{CI}$ $=(1,022,01,043)(\mathrm{p}$ value $=0.000000)-$ the presence of increased age values is a risk factor.

The ROC curve was constructed for age in the discrimination of death in the 391 patients involved in the study, of which 379 died $(96.93 \%)$ and 12 survivors (3.07\%). It has an area of 0.764 , with $95 \%$ CI of (0.718 to 0.805$)$, p_value $=<0.0001$. The cutoff point is $>61$, with a sensitivity of 68.9 and a specificity of 75.00 (Fig. 1).

The mean survival time in patients with cutoff value for age $<=61$ was $24,376,95 \%$ CI $=(21,470,27,282)$ and in those with cutoff $>61$ was $17,646,95 \%$ CI $=(16,010,19,282)$, the difference between survival time in patients with values above cutoff and below cutoff being statistically significant (p_value = 0.000049) (Table 1, Fig. 2).

Of the 150 patients with abdominal surgery history, 147 died and $3(2 \%)$ survived until 01.10.2019. Of the 241 patients without abdominal surgery history, 232 died and 9 (3.7\%) survived until the end of the study. Comparing the survival on the 2 groups, a statistically significant difference is observed (p_value $=0.031725)$.

The mortality risk for patients past surgical history (abdominal) was - HR $=1.116,95 \% \mathrm{CI}$ (1.006.1.238) $(\mathrm{p}$ value $=0.038236)$. The 5-year survival rate of those patients is $1.5 \%$ and for those without abdominal surgical history, the 5-year survival is $1.7 \%$ (Table 1).

Of the 121 patients with heart disease, 119 died by 01.10 .2019 and $2(1.7 \%)$ survived. Of the 270 patients without associated cardiac diseases, 260 died, and $10(3.7 \%)$ were alive at the end of the study. Comparing the survival on the 2 groups, there is a statistically significant difference ( $p \_v a l u e=0$, 000007).

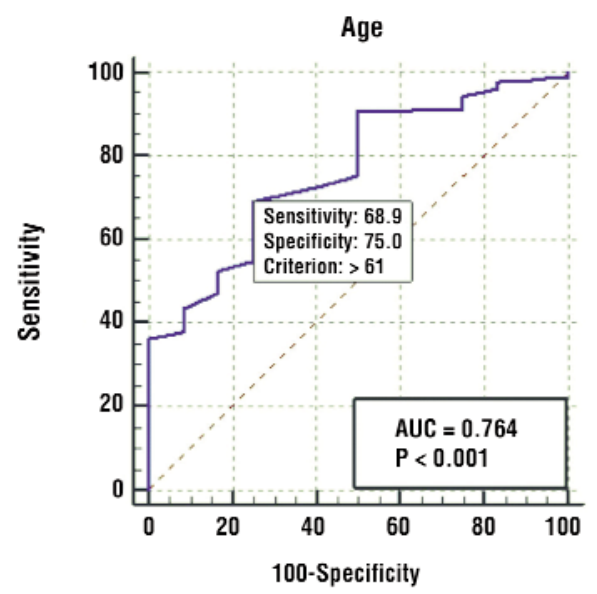

Figure 1. ROC curve for age

The mortality risk in cases with associated cardiac disease was - $\mathrm{HR}=1.247,95 \% \mathrm{CI}$ $(1.141 .1,422)(\mathrm{p}$ value $=0.000016)$. In this cases the 5 -years survival is $0 \%$, while in the patients without cardiac disease, the 5-year survival is $2.4 \%$ (Table 1 ).

Of the 27 patients with permanent atrial fibrillation history, none survived until 01.10.2019. Of the 364 without atrial fibrillation, 352 died and 12 (3.3\%) survived. Comparing the survival on the 2 groups, there is a statistically significant difference (p_value $=0.007496)$.

The risk of death in cases that presented with atrial fibrillation was - HR $=1.293,95 \%$

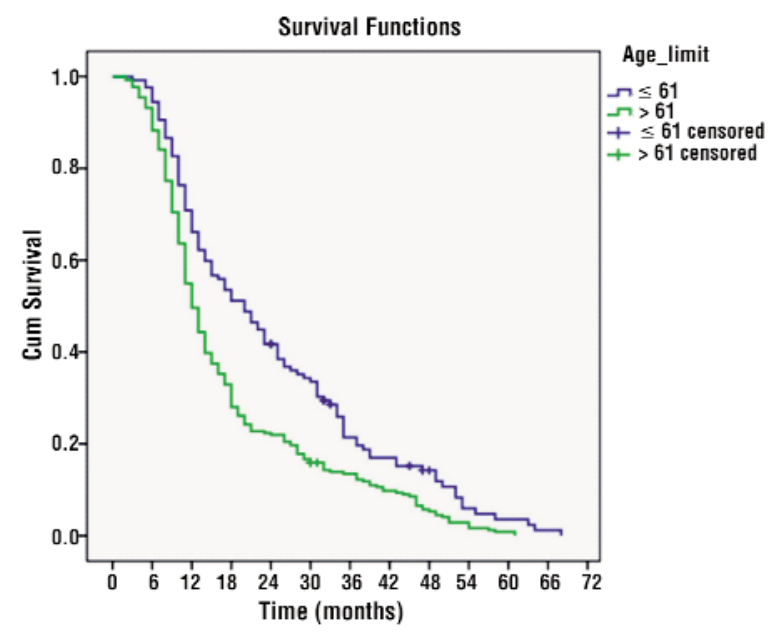

Figure 2. Survival curves for age variable with cut-off value (C) 
Table 1. Survival analysis of prognostic factors - u- univariate, $\mathrm{m}$ - multivariate, ref- reference

\begin{tabular}{|c|c|c|c|c|c|c|c|c|c|}
\hline \multirow{2}{*}{$\begin{array}{l}\text { Prognostic } \\
\text { factor }\end{array}$} & \multirow[t]{2}{*}{ Deaths } & \multirow{2}{*}{$\begin{array}{l}\text { Mean } \\
\text { Estimate }\end{array}$} & \multirow{2}{*}{$\begin{array}{l}\text { Median } \\
\text { Estimate }\end{array}$} & \multirow{2}{*}{$\begin{array}{l}5 \text {-y survival } \\
\text { rate }(\%)\end{array}$} & \multirow{2}{*}{$\begin{array}{c}\text { p_value } \\
\text { (Log Rank } \\
\text { (Mantel-Cox) }\end{array}$} & \multicolumn{2}{|c|}{ Univariate } & \multicolumn{2}{|c|}{ Multivariate } \\
\hline & & & & & & HR (95\%Cl) & p_value & HR (95\%Cl) & p_value \\
\hline \multicolumn{10}{|l|}{ Age } \\
\hline$<61$ & $118 / 127$ & 24.376 & 20.000 & & 0.000049 & 1.032 & 0.000000 & 1.026 & 0.000139 \\
\hline$>61=$ ref & $261 / 264$ & 17.646 & 12.000 & & & $(1.022,1.043)$ & & $(1.012,1.039)$ & \\
\hline \multicolumn{10}{|l|}{ Sex } \\
\hline $\mathrm{F}$ & $153 / 159$ & & & & 0.348363 & & 0.364690 & & \\
\hline M & $226 / 232$ & & & & & & & & \\
\hline \multicolumn{10}{|c|}{ Provenience area } \\
\hline $\mathrm{R}$ & $146 / 152$ & & & & 0.465583 & & 0.480728 & & \\
\hline U & $233 / 239$ & & & & & & & & \\
\hline \multicolumn{10}{|l|}{$\mathrm{HCA}$} \\
\hline YES & $38 / 38$ & & & & 0,857916 & & 0.862515 & & \\
\hline NO & $341 / 353$ & & & & & & & & \\
\hline Surgical abdo & history & & & & & & & & \\
\hline YES & $147 / 150$ & 17.931 & 11.000 & $1.5 \%$ & 0,031725 & 1.116 & 0.038236 & & \\
\hline NO & $232 / 241$ & 20.989 & 15.000 & $1.7 \%$ & & $(1.006,1.238)$ & & & \\
\hline Colonic resec & ntec. & & & & & & & & \\
\hline YES & $374 / 386$ & & & & 0,186804 & & 0.207577 & & \\
\hline NO & $379 / 391$ & & & & & & & & \\
\hline Cardiac disea & & & & & & & & & \\
\hline YES & $119 / 121$ & 15.464 & 11.000 & $\operatorname{Max} 54$ & 0,000007 & 1.274 & 0.000016 & & \\
\hline NO & $260 / 270$ & 21.766 & 16.000 & $2.4 \%$ & & $(1.141,1.422)$ & & & \\
\hline Atrial fibrillati & & & & & & & & & \\
\hline YES & $27 / 27$ & 13.889 & 10.000 & $\operatorname{Max} 49$ & 0,007496 & 1.293 & 0.010431 & & \\
\hline NO & $352 / 364$ & 20.260 & 14.000 & $1.8 \%$ & & $(1.062,1.574)$ & & & \\
\hline Cirrhosis & & & & & & & & & \\
\hline YES & $6 / 6$ & & & & 0,106936 & & 0.125853 & & \\
\hline NO & $373 / 385$ & & & & & & & & \\
\hline Bowel pathol & & & & & & & & & \\
\hline YES & $16 / 16$ & & & & 0,571957 & & 0.125853 & & \\
\hline NO & $363 / 375$ & & & & & & & & \\
\hline Abdo pain & & & & & & & & & \\
\hline YES & $336 / 346$ & & & & 0,748323 & & 0.756490 & & \\
\hline NO & $43 / 45$ & & & & & & & & \\
\hline Bowel habit d & & & & & & & & & \\
\hline Yes & $333 / 343$ & & & & 0,834845 & & 0.840303 & & \\
\hline No & $46 / 47$ & & & & & & & & \\
\hline Pre op Dg & & & & & & & & & \\
\hline $\mathrm{H}$ & $41 / 43$ & 20.579 & 14.000 & $3.6 \%$ & 0.034352 & & & & \\
\hline I & $12 / 12$ & 11.333 & 9.000 & $\operatorname{Max} 51$ & & & & & \\
\hline 0 & $305 / 314$ & 20.248 & 14.000 & $1.5 \%$ & & $1.750(1.118,2.738)$ & 0.014287 & & \\
\hline$P=$ Ref & $21 / 22$ & 16.818 & 12.000 & $\operatorname{Max} 52$ & & $.800(.647, .990)$ & 0.0398 & & \\
\hline Cachexia & & & & & & & & & \\
\hline Yes & $95 / 98$ & 13.875 & 10.000 & $\operatorname{Max} 51$ & 0,000000 & 1.371 & 0.000000 & 1.358 & 0.021617 \\
\hline No & $284 / 293$ & 21.814 & 16.000 & $2.1 \%$ & & $(1.218,1.543)$ & & $(1.046,1.764)$ & \\
\hline anuria & & & & & & & & & \\
\hline Yes & $88 / 88$ & 11.455 & 10.000 & $\operatorname{Max} 48$ & 0,000000 & 1.585 & 0.000000 & & \\
\hline No & $291 / 303$ & 22.249 & 16.000 & $2.1 \%$ & & $(1.400,1.796)$ & & & \\
\hline Anemia & & & & & & & & & \\
\hline Yes & $251 / 260$ & 17.124 & 12.000 & $1.2 \%$ & 0,000006 & 1.272 & 0.000015 & & \\
\hline No & $128 / 131$ & 25.151 & 18.000 & $2.5 \%$ & & $(1.141,1.418)$ & & & \\
\hline Transfusion & & & & & & & & & \\
\hline Yes & $79 / 81$ & & & & 0,921275 & & 0.923898 & & \\
\hline No & $300 / 310$ & & & & & & & & \\
\hline High WBC & & & & & & & & & \\
\hline Yes & $45 / 46$ & & & & 0,099868 & & 0.112409 & & \\
\hline No & $334 / 345$ & & & & & & & & \\
\hline Low PLT & & & & & & & & & \\
\hline Yes & $6 / 6$ & & & & 0,106936 & & 0.125853 & & \\
\hline No & $373 / 385$ & & & & & & & & \\
\hline Electrolite dis & & & & & & & & & \\
\hline Yes & $138 / 139$ & 15.061 & 11.000 & $0.8 \%$ & 0,000001 & 1.291 & 0.000002 & & \\
\hline No & $241 / 252$ & 22.435 & 16.000 & $2.1 \%$ & & $(1.1611 .435)$ & & & \\
\hline
\end{tabular}




\begin{tabular}{|c|c|c|c|c|c|c|c|c|c|}
\hline \multirow{2}{*}{$\begin{array}{l}\text { Prognostic } \\
\text { factor }\end{array}$} & \multirow[t]{2}{*}{ Deaths } & \multirow{2}{*}{$\begin{array}{l}\text { Mean } \\
\text { Estimate }\end{array}$} & \multirow{2}{*}{$\begin{array}{l}\text { Median } \\
\text { Estimate }\end{array}$} & \multirow{2}{*}{$\begin{array}{l}\text { 5-y survival } \\
\text { rate }(\%)\end{array}$} & \multirow{2}{*}{$\begin{array}{c}\text { p_value } \\
\text { (Log Rank } \\
\text { (Mantel-Cox) }\end{array}$} & \multicolumn{2}{|c|}{ Univariate } & \multicolumn{2}{|c|}{ Multivariate } \\
\hline & & & & & & HR (95\%Cl) & p_value & HR (95\%Cl) & p_value \\
\hline \multicolumn{10}{|l|}{ Tum location } \\
\hline Ascend & $54 / 55$ & 23.590 & 20.000 & $1.9 \%$ & 0.000030 & & & & \\
\hline Descend & $52 / 54$ & 16.706 & 12.000 & $\operatorname{Max} 47$ & & & & & \\
\hline Rect & $135 / 136$ & 15.327 & 11.000 & $1.7 \%$ & & & & & \\
\hline Sigmoid & $113 / 120$ & 24.284 & 18.000 & $2.1 \%$ & & $1.348(1.125,1.614)$ & 0.001207 & & \\
\hline Transvers $=$ Ref & $25 / 26$ & 20.269 & 13.000 & $\operatorname{Max} 50$ & & $.757(.627, .913)$ & 0.003560 & & \\
\hline \multicolumn{10}{|l|}{ Vicinity invasion } \\
\hline Yes & $107 / 107$ & 9.449 & 9.000 & $\operatorname{Max} 35$ & 0,000000 & $2.110(1.857,2.398)$ & 0.000000 & & \\
\hline No & $272 / 284$ & 23.725 & 18.000 & $2.2 \%$ & & & & & \\
\hline \multicolumn{10}{|l|}{ Frozen Pelvis } \\
\hline Yes & $34 / 34$ & 7.000 & 7.000 & $\operatorname{Max} 13$ & 0,000000 & $2.745(2.254,3.344)$ & 0.000000 & & \\
\hline No & $345 / 357$ & 21.036 & 15.000 & $1.8 \%$ & & & & & \\
\hline \multicolumn{10}{|l|}{ Carcinomatosis } \\
\hline Yes & $10 / 10$ & 6.600 & 6.000 & $\operatorname{Max} 10$ & 0,000000 & $2.631(1.897,3.648)$ & 0.000000 & 2.346 & 0.017253 \\
\hline No & $369 / 381$ & 20.162 & 14.000 & $1.7 \%$ & & & & $(1.163,4.732)$ & \\
\hline \multicolumn{10}{|l|}{ LIVER mets } \\
\hline Yes & $68 / 68$ & 8.515 & 8.000 & $\operatorname{Max} 41$ & 0,000000 & 2.271(1.959, 2.633) & 0.000000 & & \\
\hline No & $311 / 323$ & 22.196 & 17.000 & $2.0 \%$ & & & & & \\
\hline \multicolumn{10}{|l|}{ Operation } \\
\hline 1 & $154 / 155$ & 14.010 & 10.000 & $1.5 \%$ & 0.000000 & $2.405(1.827,3.166)$ & 0.000000 & $.187(.045, .779)$ & 0.021281 \\
\hline 2 & $117 / 124$ & 24.177 & 18.000 & $2.2 \%$ & & $7.693(4.797,12.338)$ & 0.000000 & & \\
\hline $3=\operatorname{ref}(m)$ & $27 / 27$ & 8.222 & 8.000 & $\operatorname{Max} 13$ & & & & & \\
\hline $4=\operatorname{ref}(u)$ & $81 / 85$ & 27.585 & 23.000 & $1.5 \%$ & & & & & \\
\hline Nodes excision & & & & & & & & & \\
\hline Yes & $72 / 76$ & 29.226 & 25.000 & $1.6 \%$ & 0,000001 & $.737(.648, .839)$ & 0.000004 & & \\
\hline No & $307 / 315$ & 17.544 & 12.000 & $1.2 \%$ & & & & & \\
\hline Liver biopsy & & & & & & & & & \\
\hline Yes & $13 / 14$ & 14.143 & 10.000 & $\operatorname{Max} 41$ & 0,043483 & $1.316(.996,1.738)$ & 0.053414 & & \\
\hline No & $366 / 377$ & 20.029 & 14.000 & $1.7 \%$ & & & & & \\
\hline Primary closure & & & & & & & & & \\
\hline Yes & $373 / 383$ & & & & 0,103058 & & 0.120910 & & \\
\hline No & $6 / 6$ & & & & & & & & \\
\hline Pulmonary compl & & & & & & & & & \\
\hline Yes & $45 / 45$ & & & & 0,774076 & & 0.781227 & & \\
\hline No & $334 / 346$ & & & & & & & & \\
\hline Redo laparotomy & & & & & & & & & \\
\hline Yes & $21 / 22$ & & & & 0,768389 & & 0.776511 & & \\
\hline No & $358 / 369$ & & & & & & & & \\
\hline Colostomy reversal & & & & & & & & & \\
\hline Yes & $49 / 57$ & 39.156 & 35.000 & $4.9 \%$ & 0,000000 & $.175(.124, .247)$ & 0.000000 & & \\
\hline No & $201 / 201$ & 10.965 & 11.000 & $\operatorname{Max} 28$ & & & & & \\
\hline Multiple surgeries & & & & & & & & & \\
\hline Yes & $72 / 80$ & 37.437 & 35.000 & $6.4 \%$ & 0,000000 & $.216(.167, .279)$ & 0.000000 & $.282(.144, .551)$ & 0.000213 \\
\hline No & $228 / 228$ & 10.640 & 10.000 & $\operatorname{Max} 28$ & & & & & \\
\hline pTNM & & & & & & & & & \\
\hline $2=$ ref & $10 / 96$ & 40.415 & 39.000 & $5.9 \%$ & 0,000000 & 25.482 & 0.000000 & 11.114 & 0.000000 \\
\hline 3 & $214 / 216$ & 13.348 & 12.000 & $\operatorname{Max} 30$ & & $(15.585,41.663)$ & 0.000000 & $(4.835,25.595)$ & \\
\hline 4 & 69/69 & 8.029 & 8.000 & Max 13 & & $\begin{array}{c}105.648 \\
(59.575,187.354)\end{array}$ & & $\begin{array}{c}36.745 \\
(14.778,91.366)\end{array}$ & 0.000000 \\
\hline Pathology & & & & & & & & & \\
\hline ADK & $378 / 390$ & & & & 0,172264 & & 0.212241 & & \\
\hline GIST & $1 / 1$ & & & & & & & & \\
\hline Grading & & & & & & & & & \\
\hline $1=$ ref & $101 / 106$ & 21.397 & 14.000 & $1.4 \%$ & 0.007069 & $1.814(1.224,2.689)$ & 0.003003 & & \\
\hline 2 & $244 / 251$ & 20.026 & 14.000 & $1.9 \%$ & & & & & \\
\hline 3 & $34 / 34$ & 13.353 & 11.000 & Max 53 & & & & & \\
\hline Mucinous type & & & & & & & & & \\
\hline Yes & $16 / 16$ & & & & 0.270325 & & 0.288271 & & \\
\hline No & $363 / 375$ & & & & & & & & \\
\hline
\end{tabular}


CI $(1.0621 .1 .574)(\mathrm{p}$ value $=0.010431)$. We found that the 5-year survival of cases with atrial fibrillation is $0 \%$, while in patients without atrial fibrillation, the 5-year survival is 1.8\% (Table 1).

Of the 43 patients with hemorrhagic tumors at admission, 41 died by the end of the study and $2(4.7 \%)$ survived. Of the 12 patients who presented with diastatic perforation imminence, none were alive at the end of the study. Of the 314 patients with intestinal occlusions /subocclusions, 305 died and 9 (2.9\%) survived until the end of the study.Of the 22 patients with intestinal perforation, 21 died and one (4.5\%) survived by the end of the study. Comparing the survival on the 4 groups, there is a statistically significant difference (p_value $=0.034352)$, more precisely, significant differences between patients with hemorrhage and those with imminent diastatic perforation $(p$-value $=0.011984)$ and between those with imminence of diastatic perforation and those with intestinal occlusion ( $\mathrm{p}$-value $=$ 0.006827) (Fig. 3).

The risk of death for patients operated for the imminent diastatic perforation was $-\mathrm{HR}=$ $1,750,95 \%$ CI $(1,118,2.738)$ (p_value $=0.014287)$, and of those with occlusion - HR $=0.800,95 \% \mathrm{CI}$ (0.647.0.990) (p_value $=0.039869)$, compared with those with perforated tumors.The 5-years survival of patients with hemorrhage at

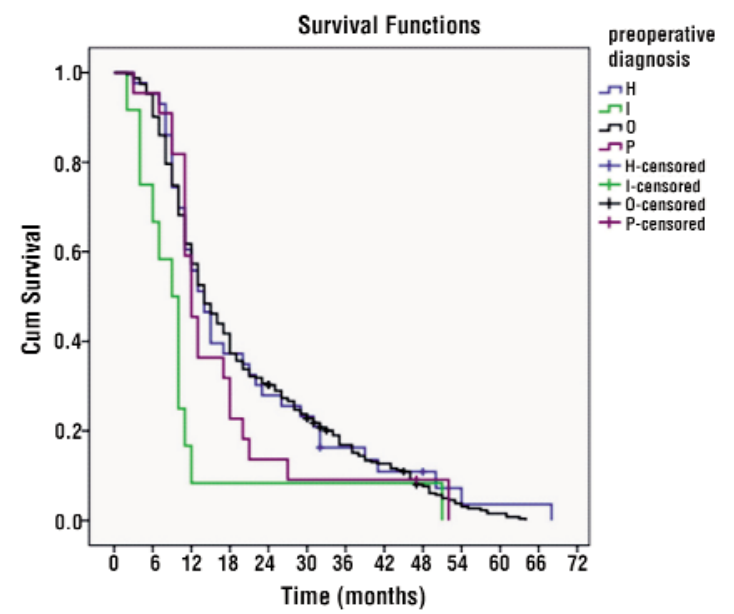

Figure 3. Survival curves Kaplan Meier according to the preoperative diagnosis admission is $3.6 \%$, while in patients with imminent diastatic perforation it is $0 \%$. For patients with intestinal occlusion at admission, the 5 -years survival is $1.5 \%$ and for those with intestinal perforation it is $0 \%$ (Table 1).

Of the 98 patients who presented with cachexia at admission, 95 died and 3 (3.1\%) survived until 01.10.2019. Of the 293 patients without cachexia, 284 died and 9 (3.1\%) were alive at the end of the study. Comparing the survival on the 2 groups, there is a statistically significant difference (p_value $=0.000000$ ).

The risk of death in patients with casexia was $-H R=1.371,95 \%$ CI $(1.218 .1 .543)$ ( $p$ value $=0.000000)$. The 5-year survival of patients with cachexia is $0 \%$, while in those without cachexia, the 5 -year survival is $2.1 \%$ (Table 1).

Of the 88 patients with oliguria at admission, none survived until 01.10.2019. Of the 303 patients with normal diuresis, 291 died and $12(4.0 \%)$ were alive by the end of the study. Comparing the survival on the 2 groups, there is a statistically significant difference (p_value $=0.000000$ ) .

Death risk for oliguric patient was - HR = $1.585,95 \%$ CI $(1.400 .1 .796) \quad(\mathrm{p}$ value $=$ $0.000000)$. The 5-years survival of patients with oliguria is $0 \%$, while in patients without oliguria, the 5-years survival is $2.1 \%$ (Table 1 ).

Of the 260 patients admitted with anemia, 251 died and 9 (3.5\%) survived until 01.10.2019. Of the 131 patients without anemia at admission, 128 died and $3(2.3 \%)$ were alive by the end of the study. Comparing the survival on the 2 groups, there is a statistically significant difference $\left(p \_v a l u e=0.000006\right)$. The mortality risk for patients with oliguria was - $\mathrm{HR}=1.585$, 95\% CI(1.400.1.796) (p_value 0.000000). The 5years survival of patients with anemia at admission is $1.2 \%$, while for patients without anemia, the 5 -year survival is $2.5 \%$ (Table 1 ).

Of the 139 patients with hydro-electrolytic disorders at admission, 138 died and one survived until 01.10.2019. Of the 252 patients without hydro-electrolyte disorders, 241 died and $11(4.4 \%)$ were alive by the end of the study. Comparing the survival on the 2 groups, a statistically significant difference is 
obtained $\left(p \_v a l u e=0.000001\right)$. For patients with electrolyte imbalance the risk of death was - HR $=1.291,95 \%$ CI $(1.161 .1,435)$ $(\mathrm{p}$ value $=0.000002)$. The 5-years survival of patients with hydro-electrolyte disorders at admission is $0.8 \%$, while for patients without hydro-electrolyte disorders, the 5-years survival is $2.1 \%$ (Table 1 ).

Of the 55 patients with tumors in right colon, 54 died by the end of the study and one (1.8\%) survived. Of the 26 patients with transverse colon tumors, 25 died and 1 (3.8\%) was alive at the end of the study. Of the 54 patients with descending colon tumors, 52 died and $2(3.7 \%)$ survived until the end of the study. Of the 120 patients with sigmoid colon tumors and recto-sigmoid junction, 113 died and $7(5.8 \%)$ were alive at the end of the study. Of the 136 patients with rectal tumors, 135 died and $1(0.7 \%)$ survived by the end of the study. Comparing the survival on the 5 groups, a statistically significant difference (p_value $=0.000030$ ) is obtained, more precisely, there are statistically significant differences between the locations on the ascendant and descendant colon (p_value = 0.018036), between the locations on the ascendant colon and the rectum (p_value = 0.003738), between the locations on the descendant and on the sigmoid (p_value = 0.000819 ) and between the locations on the rectum and the sigmoid $\left(p_{\text {_value }}=0.000003\right)$ (Fig. 4).

The risk of death in patients operated for rectal tumors was - $\mathrm{HR}=1.348,95 \% \mathrm{CI}$ (1.125, 1.614) (p_value $=0.001207)$, and of those with sigmoid tumors - HR $=0.757,95 \%$ CI $(0.627$, $0.913)$ (p_value $=0.003560)$, compared with those with transverse tumors. The 5-years survival of patients with ceco-ascendant tumors is $1.9 \%$, while in patients with descendant tumors, the 5-years survival is $0 \%$. For patients with rectal tumors, the 5year survival is $1.7 \%$, for those with sigmoid tumors $2,1 \%$, and for those with transverse colon tumors $0 \%$ (Table 1).

Of the 107 patients with tumor invasion in other organs, none survived until 01.10.2019. Of the 284 patients without tumor invasion in other organs, 272 died and $12(4.2 \%)$ were alive at the end of the study. Comparing the survival on the 2 groups, there is a statistically significant difference (p_value $=0.000000$ ).

The risk of death for patients with tumor invasion in the neighboring organs was - $\mathrm{HR}=$ $2.110,95 \%$ CI $(1.857,2.398)(\mathrm{p}$ value $=$ $0.000000)$. The 5-years survival of patients with invasive tumors in other organs is $0 \%$ and in patients with non-invasive tumors, the 5-years survival is $2.2 \%$ (Table 1 ).

Of the 34 patients with "frozen pelvis", none survived until 01.10.2019. Of the 357 patients without "frozen pelvis", 345 died and $12(3.4 \%)$ were alive at the end of the study. Comparing the survival on the 2 groups, there is a statistically significant difference (p_value $=0.000000$ ).

The risk of death in patients with frozen pelvis was $-\mathrm{HR}=2.2745,95 \% \mathrm{CI}(2.254 .3344)$ ( $p$ value $=0.000000)$. The 5-years survival of patients with "frozen pelvis" is $0 \%$, while in patients without "frozen pelvis", the 5-year survival is $1.8 \%$ (Table 1 ).

Of the 10 patients with peritoneal carcinomatosis, none survived until 01.10.2019. Of the 381 patients without peritoneal carcinomatosis, 369 died and $12(3.1 \%)$ were alive at the end of the study. Comparing the survival on the 2 groups, we found a statistically significant difference (p_value $=0.000000)$.

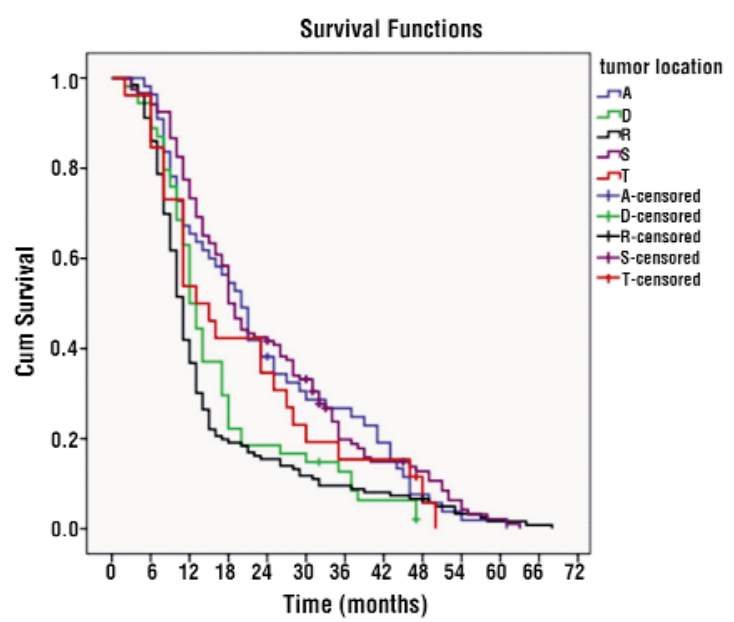

Figure 4. Survival curves Kaplan Meier depending on tumor location 
The risk of death in patients with carcinomatosis was $-\mathrm{HR}=2.631,95 \%$ CI $(1.897$, $3.648)(\mathrm{p}$ value $=0.000000)$. The 5 -years survival of patients with peritoneal carcinomatosis is $0 \%$, while in patients without peritoneal carcinomatosis, the 5-years survival is $1.7 \%$ (Table 1$)$.

Of the 68 patients with liver metastases, none survived until 01.10.2019. Of the 323 patients without liver metastases, $12(3.7 \%)$ survived by the end of the study. Comparing the survival on the 2 groups, there is a statistically significant difference ( $p_{-}$value = 0.000000 Log Rank (Mantel-Cox)).

The risk of death in patients with hepatic metastases was - HR $=2.271,95 \%$ CI $(1.959 .2 .633)(\mathrm{p}$ value $=0.000000)$. The 5 -years survival of patients with hepatic metastases is $0 \%$, while in patients without hepatic metastases, the 5-years survival is $2.0 \%$ (Table 1 ).

Of the 155 patients with colostomies, 154 died and $1(0.6 \%)$ survived until 01.10.2019. Of the 124 patients who underwent Hartmann interventions, 117 died and 7 (5.6\%) were alive at the end of the study. Of the 27 patients who underwent internal derivations, none survived until the end of the study and of the 85 patients with resections with anastomosis, 81 died and $4(4.7 \%)$ survived until the end of this study. Comparing the survival on the 4 groups, we found a statistically significant difference (p_value $=0.000000$ Log Rank (Mantel-Cox)), more precisely: significant differences between patients with colostomies and those with Hartmann operations ( $\mathrm{p}$ value $=0.000000$ ), between those with colostomies and those with resections with anastomosis ( $\mathrm{p}$ value $=0.000057)$, between those with Hartmann operations and those with internal derivations ( $p$ value $=0.000000$ ), but also between those with internal derivations and those with resections with anastomosis ( $\mathrm{p}$ value $=0.000000)($ Fig. 5) .

The risk of death in patients with colostoma was $-\mathrm{HR}=2.405,95 \%$ CI $(1.827$, 3.166) (p_value $=0.000000)$, and of those with internal derivatives $-\mathrm{HR}=7.693,95 \% \mathrm{CI}$ $(4.797,12.338)$ (p_value $=0.000000), \mathrm{com}^{-}$ pared with those with resection-anastomosis.
The 5-years survival of patients with colostomies is $1.5 \%$, of those with Hartmann's operations is $2.2 \%$, ofthose with internal derivations is $0 \%$ and for those with resections with anastomosis $1.5 \%$ (Table 1 ).

Of the 76 patients who underwent lymph node dissection during the emergency intervention, 72 died and 4 (5.3\%) survived until 01.10.2019. Of the 315 patients without lymph node dissection, 307 died and 8 (2.5\%) were alive at the end of the study. Comparing the survival on the 2 groups, there is a statistically significant difference (p_value $=$ 0.000001).

The risk of death in patients with lymph node dissection was $-\mathrm{HR}=0.737,95 \% \mathrm{CI}$ $(0.648 .0 .839)(\mathrm{p}$ value $=0.000004)$. The 5-years survival of patients with lymph node dissection is $1.6 \%$, while in patients without lymph node dissection, the 5-years survival is $1.2 \%$ (Table 1).

Of the 14 patients who underwent hepatic biopsy of tumor formations with metastasis appearance, 13 died and 1 (7.1\%) survived until 01.10.2019. Of the 377 patients without liver biopsy, 366 died and 11 (2.9\%) were alive at the end of the study. Comparing the survival on the 2 groups, there is a statistically significant difference (p_value $=0.043483$ ) .

The risk of death in patients with liver biopsy was $-\mathrm{HR}=1.316,95 \% \mathrm{CI}(0.996,0.839)$

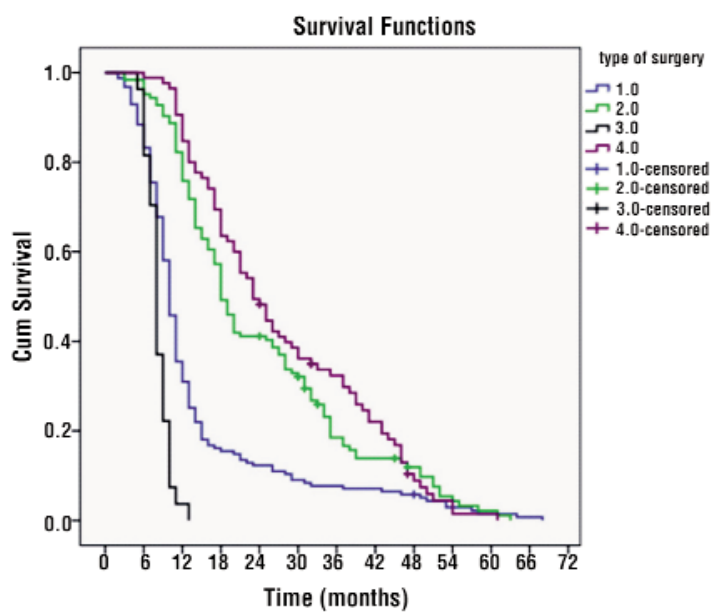

Figure 5. Survival curves Kaplan Meier according to the type of surgery 
$(\mathrm{p}$ value $=0.000004)$.The 5-years survival of patients with liver biopsy was $0 \%$, while in patients without liver biopsy, the 5-years survival was $1.7 \%$ (Table 1 ).

Of the 57 patients who underwent stoma reversal after Hartmann interventions, 49 died and 8 (14\%) survived until 01.10.2019. Of the 201 patients without stoma reversal, none survived until the end of the study. Comparing the survival on the 2 groups, there is a statistically significant difference ( $p_{\text {_value }}=$ 0.000000).

The risk of death for patients with reintegration was $-\mathrm{HR}=0.175,95 \% \mathrm{CI}(0.124,0.247)$ ( $\mathrm{p}$ value $=0.000000)$. The 5-years survival of patients with reintegration is $4.9 \%$, while in patients without reintegration, the 5-years survival is $0 \%$ (Table 1 ).

Of the 80 patients who underwent serial interventions, 72 died and $8(10 \%)$ survived until 01.10.2019. Of the 228 patients without serial interventions, none survived until the end of the study. Comparing the survival on the 2 groups, there is a statistically significant difference (p_value $=0.000000)$.

The risk of death for patients with serious interventions was - $\mathrm{HR}=0.216,95 \% \mathrm{CI}(0.167$, $0.279)(\mathrm{p}$ value $=0.000000)$. The 5 -years survival of patients with serial interventions is $6.4 \%$, while in the patients without serial interventions, the 5-years survival is $0 \%$ (Table 1).

Of the 106 patients with stage II pTNM, 96 died and $10(9.4 \%)$ survived until 01.10.2019. Of the 216 patients with stage III pTNM, 214 died and $2(0.9 \%)$ were alive at the end of the study. Of the 69 patients with stage IV pTNM, none survived until the end of the study. Comparing the survival in the 3 groups, we found a statistically significant difference (p_value $=0.000000)$, more precisely, significant differences were obtained between the stages pTNM II-III, II-IV and III-IV (p_value $=0.000000)$ (Fig. 6).

The mortality risk in stage 3 patients was $\mathrm{HR}=25,482,95 \% \mathrm{CI}(15,585,41,663)$ (p_value $=0.000000)$, and of those with stage $4-\mathrm{HR}=$ $105,648,95 \%$ CI $(59,575,187,354)$ (p_value $=$ $0.000000)$, compared to those with stage 2 .
The 5-years survival for cases in stage II pTNM is $5.9 \%$, while in the patients with stages III and IV pTNM, the 5-years survival is $0 \%$ (Table 1).

Of the 106 patients with well-differentiated tumors, 101 died and 5 (4.7\%) survived until 01.10.2019. Of the 251 patients with moderatedifferentiated tumors, 244 died and 7 (2.8\%) were alive at the end of the study. Of the 34 patients with poorly differentiated tumors, none survived until the end of the study. Comparing the survival on the 3 groups, we found a statistically significant difference (p_value $=0.007069$ ), more precisely: a signifi ${ }^{-}$ cant difference between grading 1 and $3(\mathrm{p}$ value $=0.002739)$ and between grading 2 and $3(\mathrm{p}$ value $=0.004252)($ Fig. 7$)$.

The risk of death in patients with poorly differentiated tumors was $-\mathrm{HR}=1,814$, $95 \%$ CI $(1,224,2,689)(\mathrm{p}$ value $=0.003003)$ compared to well differentiated tumors. The 5 -years survival for grade 1 tumors is $1.4 \%$, in patients with grade 2 tumors, the 5-year survival is $1.9 \%$ and for those with grade 3 tumors is $0 \%$ (Table 1 ).

\section{Multivariate Analysis}

We entered the data after eliminating the variables without statistical significance, and selected the final values with statistical significance.

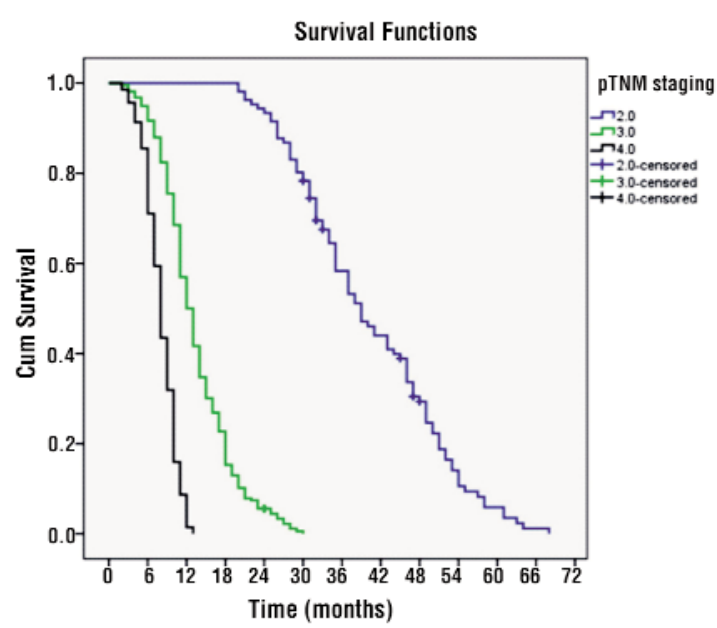

Figure 6. Survival curves Kaplan Meier according to pTNM staging 


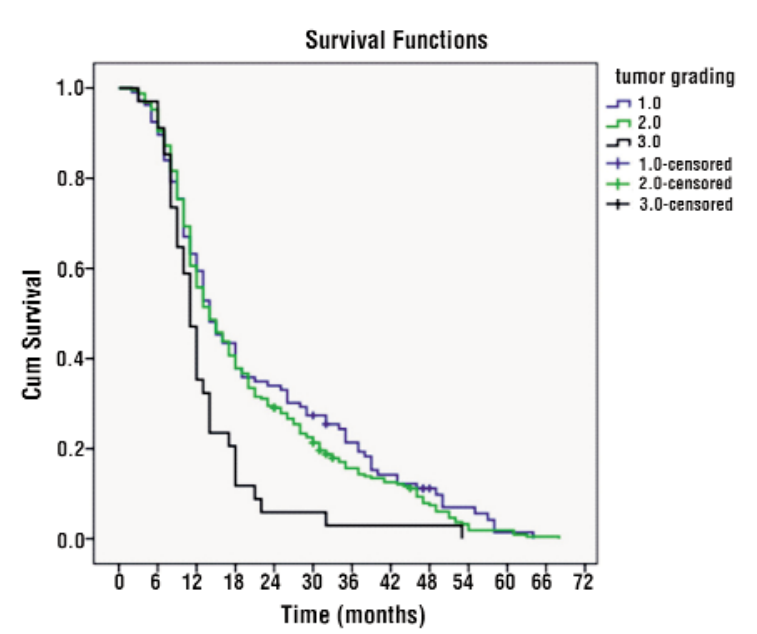

Figure 7. Survival curves Kaplan Meier according to tumor grading

Comparing the survival in patients aged $>61$ with those $<61$, but with the same values for cachexia, carcinomatosis, type of operation, stage of disease and serial interventions, the risk of death in patients $>61$ years old were calculated $-\mathrm{HR}=1.026,95 \% \mathrm{CI}=(1.012$, 1.039) $\left(\mathrm{p} \_\right.$value $\left.=0.000139\right)($ Table 1$)$, so age $>$ 61 is an independent risk factor.

Comparing the survival in patients with cachexia with those without cachexia, but with the same values for age, carcinomatosis, type of operation, stage of disease and serial interventions, the risk of dying was calculated for patients with cachexia - $\mathrm{HR}=1,358,95 \% \mathrm{CI}$ $=(1,046,1.764)\left(\mathrm{p} \_\right.$value $\left.=0.021617\right)($ Table 1$)$, so the presence of cachexia was demonstrated as an independent risk factor. Survival comparison of cases with peritoneal carcinomatosis with those without carcinomatosis, but with the same values for the other variables, the risk of death was calculated for patients with carcinomatosis - $\mathrm{HR}=2,346$, $95 \%$ CI $=(1,163,4,732)($ p_value $=0.017253)$ (Table 1), so the presence of peritoneal carcinomatosis is an independent risk factor.

Comparing the survival in patients with Hartmann operations with those with internal derivations, but with the same values for age, cachexia, carcinomatosis, disease status and serial interventions, the risk of dying was calculated for patients with Hartmann procedure $-\mathrm{HR}=0.187,95 \% \mathrm{CI}(0.045,0.779)$ (p_value $=0.021281)($ Table 1$)$, so the Hartmann procedure is an independent protection factor.

Analyzing patients with stage IV compared with those with stage II, but with the same values for the other variables, the risk of dying was calculated for patients with stage IV tumors - $\mathrm{HR}=36,745,95 \% \mathrm{CI}=(14,778$, 91,366) (p_value $=0.000000)$ (Table 1), so stage IV is an independent risk factor.

Analyzing life spawn in patients diagnosticated with stage III with those on stage II, but with the same values for the other variables, the risk of death was calculated in the case of patients with tumors in stage III - $\mathrm{HR}=$ $11,114,95 \% \mathrm{CI}=(4,835,25.59566)\left(\mathrm{p} \_\right.$value $=$ $0.000000)$ (Table 1), so stage III disease is an independent risk factor.

Comparing the survival in patients with serial interventions with those without such interventions, but with the same values for age, cachexia, carcinomatosis, with Hartmann procedure, stage III or IV, the risk of death was calculated in patients with serial interventions $-\mathrm{HR}=0.282,95 \% \mathrm{CI}=(0.144,0.551)$ $(\mathrm{p}$ value $=000213)($ Table 1$)$, so serial interventions are an independent protection factor.

\section{Discussions}

In our study, we showed that survival of the patients with colorectal cancer in the long-term is negatively influenced by: the age of the patients ( $>61$ years), the presence of abdominal surgical history, the presence of associated cardiac diseases, especially the atrial fibrillation, the preoperative diagnosis (diastatic perforation imminence), the presence of cachexia, oliguria, anemia and the hydroelectrolyte disorders at admission, the location of the tumors at the rectal level, the presence of the tumor invasion in other organs, the appearance of "frozen pelvis", the hepatic metastases and the peritoneal carcinomatosis, the type of surgery (internal derivations), absence of lymph node dissection, absence of stoma reversal or practicing serial interventions, stage IV p TNM and poorly differentiated tumors. 
The multivariate analysis that we performed revealed the independent prognostic factors: age over 61, the presence of cachexia, peritoneal carcinomatosis, stage III and IV, while Hartmann procedure and serial interventions were independent protection factors.

In most studies, the advanced age of patients with colorectal cancer, operated in emergency, was a risk factor (13-15), as in our study. Other studies have reported a poor prognosis in young patients with colorectal neoplasm. Young patients are considered to have a poorer prognosis due to the association with the presence of undiffrentiated tumors $(16-19)$. On the contrary, in other studies it is shown that younger patients have a better survival, explained in the first place by the fact that they present in a better biological state and thus allow us to practice larger interventions (20).

The data from various published works indicate a statistically significant correlation between the long-term survival of complicated colorectal cancer cases and the association of comorbidities $(21,22)$, a correlation that we also found in our study.

Regarding the preoperative diagnosis, in our study we showed that the imminence of diastatic perforation was a risk factor. Studies on this subject are lacking. Most attribute better long-term survival to hemorrhagic tumors, possibly due to the patients' alarming and thus to an earlier presentation and diagnosis (23).

Neoplastic cachexia is a complex condition, which involves systemic inflammation, negative protein and energy balance and involuntary loss of body mass, with or without fat loss (24). In our study, neoplastic cachexia was an independent prognostic factor. Literature publications on this topic are missing.

A recent study published in Brazil, shows that anemia is a risk factor for colorectal cancer patients operated in emergency (25), as it happened in our study, and anemia with preoperative transfusion wasan independent risk factor, correlation that we did not find.

There are divergent opinions about how the tumors' location on different segments could influence the survival. One study showed that the location of the tumor under the reflection of the peritoneum on the rectum (subperitoneal rectum) decreases the 5-years survival compared to the locations on the

intraperitoneal rectum and those on the colon (26). We also found this fact in our study. Some authors have shown that primary tumors located on the left colon were associated with significantly lower risk of death and concluded that tumor location should be a criterion for establishing the prognosis $(27,28)$.

The tumor invasion in other organs was a negative prognostic factor in our study, similar to other published research (29-32).

The metastases of colorectal tumors occur most frequently in the liver, given the location of this organ in relation to the portal circulation (33). The presence of liver metastases is a unanimous negative prognostic factor for colorectal cancer patients $(34,35)$, even more for those operated in emergency.

In some studies, the colorectal cancer with peritoneal carcinomatosis operated in emergency, has been associated with the lowest survival (7). A whole series of studies that analyzed the tumor invasion of the peritoneal serous as a separate variable, have shown in multivariate analyzes, that this is an independent negative prognostic factor (36), as we have found in our study.

The results of most published studies agree that emergency surgery itself is a negative prognostic factor for the long-term survival of colorectal cancer patients (37-39).

In a study conducted recently at the University Hospital in Daejeon, Korea, it is shown the importance of choosing the type of surgeryfor colorectal cancer patients. The highest mortality was recorded in patients with colostomy, similar to the data from our study (40).

Regarding the lymph node dissection, its practice has proved to be a risk factor in our study, similar to the reports of other authors (41), but different than others' results $(42,43)$.

In a recent study conducted at Basel University Hospital, Switzerland, which included 747 colorectal cancer patients, 84 of 
which being operated in emergency, between 1989-2013, the authors showed that age, tumor location, lymphadenectomy and tumor status were independent prognostic factors for long-term survival (44).

Similar to our data, the practice of serial interventions has been shown to be a protective factor in other studies $(15,45-47)$. In contrast, other authors concluded that resections with anastomosis ensure better survival, including for occlusive tumors (48).

The stoma reversal after Hartmann procedures was also a protection factor in other studies $(49,50)$. For the patients in our group, stoma reversal was performed at an average interval of 5.7 months. In the literature, it is recommended that the restoration of the transit should be done at 6-10 months, but not later. The experience from the Dutch Rectal Cancer trial has shown that if a colostomy is not closed in the first year after surgery, it will most likely become permanent (51).

In a prospective study conducted at Cornwall Hospital in the United Kingdom, the authors demonstrated that the most important prognostic factor for long-term survival was the tumor stage (15).

Very recent studies reaffirm the significant correlation between the advanced stage of the disease (III and IV) and the long-term survival in cases with complicated colorectal cancer (52). Other authors found statistical significance only in the association of stage IV with the long-term survival (53). Some authors considered that for the stage IV of the disease, the percentage of survivors is so low that they excluded these patients from the survival analysis (54).

In our study, we also found statistical significance in correlating tumor grading with the long-term survival of patients with complicated colorectal cancer, as confirmed by other authors (55).

\section{Conclusions}

1. For cases with colorectal tumors operated in emergency, the risk factors associated with overall survival were: the age $>61$, the presence of abdominal surgical history and associated cardiac conditions, especially atrial fibrillation, diagnosis of diastatic perforation imminence, cachexia, oligoanuria, anemia and hydro-electrolyte disorders at admission, rectal tumors, tumor invasion in other organs, appearance of "frozen pelvis", presence of hepatic metastases or peritoneal carcinomatosis, stage IV tumors, practicing of internal derivations or not performing lymph node dissection.

2. In the multivariate regression analysis we found that age over 61 , cachexia, peritoneal carcinomatosis, as well as stage III or IV of the disease are independent risk factors and Hartmann procedure and serial interventions are independent protective factors.

\section{Conflict of Interest}

The authors declare no conflicts of interests.

\section{References}

1. Ferlay J, Soerjomataram I, Dikshit R, Eser S, Mathers C, Rebelo M, et al. Cancer incidence and mortality worldwide: sources, methods and major patterns in GLOBOCAN 2012. Int J Cancer 2015;136(5): E359-86

2. Bray F, Ferlay J, Soerjomataram I, Siegel RL, Torre LA, Jemal A. Global cancer statistics 2018: GLOBOCAN estimates of incidence and mortality worldwide for 36 cancers in 185 countries. CA Cancer J Clin.2018:68(6):394-424

3. Wu Q, Hu T, Zheng E, Deng X, Wang Z. Prognostic role of the lymphocyte-to-monocyte ratio in colorectal cancer: An up-to-date meta-analysis. Medicine (Baltimore). 2017;96(22):e7051.

4. Holleczek B, Rossi S, Domenic A, Innos K, Minicozzi P, Francisci $S$, et al. EUROCARE-5 Working Group. On-going improvement and persistent differences in the survival for patients with colon and rectum cancer across Europe 1999-2007 - Results from the EUROCARE-5 study. Eur J Cancer. 2015;S0959-8049(15)00704-2.

5. Smothers L, Hynan L, Fleming J, Turnage R, Simmang C, Anthony T. Emergency Surgery for Colon Carcinoma.Dis Colon Rectum 2003;46(1):24-30

6. Zaharie F, Mocan L, Mocan T, Tomus C, Hodor V, Al Hajjar N, et al. Surgical Management of Malignant Large Bowel Obstructions. Chirurgia (Bucur). 2011;106(4):479-484. Romanian

7. Barbulescu M. Factorii prognostici ai cancerului colorectal (I). Jurnalul de Chirurgie lasi. 2007;3(2):117-129.

8. Schmoll HJ, Van Cutsem E, Stein A, Valentini V, Glimelius B, Haustermans K, et al. ESMO Consensus Guidelines for management of patients with colon and rectal cancer. a personalized approach to clinical decision making. Ann Oncol. 2012;23(10): 2479-516.

9. Rawla P, Sunkara T, Barsouk A. Epidemiology of colorectal cancer: incidence, mortality, survival, and risk factors. Prz Gastroenterol. 2019;14(2):89-103

10. Yin D, Morris CR, Bates JH, German RR. Effect of misclassified 
underlying cause of death on survival estimates of colon and rectal cancer. J Natl Cancer Inst. 2011;103:1130-3.

11. McArdle CS, Hole DJ. Emergency of colorectal cancer is associated with poor 5-year survival. British Journal of Surgery 2004;91(5): 605-9.

12. Metidieri Menegozzo CA, Teixeira-Júnior F, Dias do Couto-Netto $\mathrm{S}$, Martins-Júnior 0 , de Oliveira Bernini C, Massazo Utiyama E. Outcomes of Elderly Patients Undergoing Emergency Surgery for Complicated Colorectal Cancer: A Retrospective Cohort Study. Clinics (Sao Paulo). 2019;74:e1074.

13. Fang SC, Chao TB, Tung HY, et al. Analysis of prognostic factors to predict postoperative colorectal cancer patients survival. Med J South Taiwan, 2014;10(2):75-86.

14. Yuan Y, Li MD, Hu HG, Dong CX, Chen JQ, Li XF, et al. Prognostic and survival analysis of 837 Chinese colorectal cancer patients. World J Gastroenterol. 2013;19(17): 2650-9.

15. Widdison AL, Barnett SW, Betambeau N. The impact of age on outcome after surgery for colorectal adenocarcinoma. Ann R Coll Surg Engl. 2011;93(6):445-450.

16. Bresalier R. Malignant Neoplasms of the Large Intestine,In: Feldman M, Friedman LS, SleisengerMH,editors. Gastrointestinal and Liver Disease (Pathology / Diagnosis / Management). Philadelphia, London, New York: Saunders; 2002, p. 2215-2263.

17. Rao BN, Pratt CB, Fleming ID, Dilawari RA, Green AA, Austin BA. Colon carcinomain children andadolescents: a review of 30 cases. Cancer. 1985;55(6):1322-1326.

18. Rigby CS, Subramony C, Kukora JS. Carcinoma of the colon and rectum in adolescents and young adults. Surg Gastroenterol. 1983;2:283-288.

19. Moore PA, Dilawari RA, Fidler WJ. Adenocarcinoma of the colon and rectum in patients less than 40 years. Am Surg. 1984;50:10-14.

20. Ponz de Leon M, Micheli A, Gatta G, Capocaccia R, Sant M, Gafa L, et al. Sopravvivenza per tumori del colon e del retto in Italia. (1996) Ann. Ist. Super. Sanita, 32 (4);527-536

21. Iversen LH. Aspects of survival from colorectal cancer in Denmark.Dan Med J. 2012 Apr;59(4):B4428

22. Luque-Fernandez MA, Redondo-Sanchez D, Lee SF, RodriguezBarranco M, Carmona-García MC, Marcos-Gragera $R$ et al. The pattern of comorbidities and multimorbidity among colorectal cancer patients in Spain: CoMCoR study. bioRxiv 2019;526673

23. Mogos D, Paun M. Prognosticulcancerului de colon. In: Mogos D, Vasile I, editors. Cancerul de colon. Craiova: Editura Aius; 2000. p. 503-519.

24. Fearon KCH, Strasser F, Anker SD, Bosaeus I, Bruera E, Fainsinger $\mathrm{RL}$, et al. Definition and classification of cancer cachexia: an international consensus. Lancet Oncol. 2011;12(5):489-495.

25. Ramos RF, Santos Dos-Reis LC, Beatriz EstevesBorgeth Teixeira, Andrade IM, JaquelineSuelenSulzbach, Leal RA. Cirurgia no cancer de colon empacientesoperados de emergencia. Rev Col Bras Cir 2017;44(5):465-470.

26. Freedman LS, Macaskill P, Smith AN. Multivariate analysis of prognostic factors for operable rectalcancer. Lancet. 1984; 2(8405):733-736.

27. Petrelli F, Tomasello G, Borgonovo K, Ghidini M, Turati L, Pierpaolo Dallera et al. Prognostic Survival Associated With Left-Sided vs Right-Sided Colon Cancer: A Systematic Review and Metaanalysis. JAMA Oncol. 2017:3(2): 211-219.

28. Cai X, Gu D, Chen M, Liu L, Chen D, Lu L, et al. The effect of the primary tumor location on the survival of colorectal cancer patients after radical surgery. Int J Med Sci 2018;15(14):1640-1647.

29. Campos FG, Calijuri-Hamra MC, Imperiale AR, Kiss DR, Nahas SC, Cecconello I. Locally advanced colorectal cancer: results of surgical treatment and prognostic factors. ArqGastroenterol. 2011; 48(4):270-5.

30. Perron L, Daigle JM, Vandal N, Guertin MH, Brisson J.
Characteristics affecting survival after locally advanced colorectal cancer in Quebec. CurrOncol. 2015;22(6):e485-e492.

31. Sokolov M. Surgical approach in locally advanced colorectal cancer-combined, extended and compound surgery.Khirurgiia (Sofiia).2013;(4):29-50

32. Park S, Lee YS. Analysis of the prognostic effectiveness of a multivisceral resection for locally advanced colorectal cancer. J Korean SocColoproctol. 2011;27(1):21-26.

33. Sheth KR, Clary BM. Management of hepatic metastases from colorectal cancer Clin Colon Rectal Surg. 2005 Aug;18(3):215-223

34. Tardu A, Kayaalp C, Yilmaz S, Tolan K, Ersan V, Karagul S, et al. Resection of colorectal liver metastasis with vena cava resection.Case Rep Surg. 2016;2016:1-4.

35. Valderrama-Treviño Al, Barrera-Mera B, Ceballos-Villalva JC, Montalvo-Javé EE. Hepatic Metastasis from Colorectal Cancer. Euroasian J Hepatogastroenterol. 2017;7(2):166-175

36. Compton CC, Fenoglio-Preiser CM, Pettigrew N, Fielding LP. American Joint Committee on Cancer Prognostic Factors consensus conferences: Colorectal Working Group. Cancer. 2000; 88(7): 1739-1757

37. McArdle CS, Hole DJ. Emergency presentation of colorectal cancer is associated with poor 5-year survival. Br J Surg. 2004;91(5): 605-609

38. Zuli $Y$, Wang L, Kang L, Xiang $Y$, Peng J, Cui J, et al. Clinicopathologic characteristics and outcomes of patients with obstructive colorectal cancer. J Gastrointest Surg. 2011;15(7): 1213-1222

39. Abdelrazeq AS, Scott N, Thorn C, Verbeke CS, Ambrose NS, Botelli ID, et al. The impact of spontaneous tumor perforation on outcome following colon cancer surgery.Colorectal Dis. 2008;10(8): $775-780$.

40. Kim CN. Emergent Colorectal Surgery: What Should Be Considered? AnnColoproctol. 2016;32(4):124-125.

41. Zhou YY, Zhang QW, Huang J, Yan XL, Chen C, Xu FF, et al. Additional lymphadenectomy might not improve survival of patients with resectable metastatic colorectal adenocarcinoma of T4 stage, proximal location, poor/undifferentiation, or N3/N4 stages: a large population-based study. J Cancer. 2018;9(14): 2428-2435.

42. O'Boyle S, Stephenson K. More is better: Lymph node harvesting in colorectal cancer. Am J Surg. 2017;213:926-930.

43. Aquina CT, Becerra AZ, Xu Z, Boscoe FP, Schymura MJ, Noyes K, et al. Nonelective colon cancer resection: A continued public health concern. Surgery. 2017;161(6):1609-18.

44. Weixler B, Warschkow R, Ramser M, Droeser R, von Holzen U, Oertli $D$, et al. Urgent surgery after emergency presentation for colorectal cancer has no impact on overall and disease-free survival: a propensity score analysis. BMC Cancer. 2016;16:208.

45. De Salvo GL, Gava C, Pucciarelli S, Lise M. Curative surgery for obstruction from primary left colorectal carcinoma: primary or staged resection? Cochrane Database Syst Rev. 2004;2:CD002101

46. Amelung FJ, Consten ECJ, Siersema PD, Tanis PJ. A populationbased analysis of three treatment modalities for malignant obstruction of the proximal colon: acute resection versus stent or stoma as a bridge to surgery. Ann SurgOncol. 2016;23(11):3660-3668.

47. Tebala GD, Natili A, Gallucci A, Brachini G, Qayyum Khan A, Tebala $D$, et al. Emergency treatment of complicated colorectal cancer. Cancer Manag Res. 2018;10:827-838.

48. Andreano M, D'Ambrosio V, Coretti G, Bianco P, Castriconi M. Primary anastomosis in emergency surgery of left colon cancer.AnnltalChir. 2016;87:438-441.

49. Kristiansen VB, Lausen IM, Frederiksen HJ, Kjaergaard J: Hartmann's procedure in the treatment of acute obstructive leftsided colonic cancer. UgeskrLaeger. 1993, 155: 3816-3818

50. Charbonnet P, Gervaz P, Andres A, Bucher P, Konrad B, Morel P. 
Results of emergency Hartmann's operation for obstructive or perforated left-sided colorectal cancer. World J Surg Onc. 2008:6:90.

51. den Dulk M, Smit M, Peeters KC, Kranenbarg EM, Rutten HJ, Wiggers T, et al. Dutch Colorectal Cancer Group: A multivariate analysis of limiting factors for stoma reversal in patients with rectal cancer entered into the total mesorectal excision (TME) trial: a retrospective study. Lancet Oncol.2007;8:297-303.

52. Lee CH, Cheng SC, Tung HY, Chang SC, Ching CY, Wu SF. The Risk Factors Affecting Survival in Colorectal Cancer in Taiwan. Iran J Public Health. 2018;47(4):519-530.
53. Littlechild J, Junejo M, Simons AM, Curran F, Subar D. Emergency resection surgery for colorectal cancer: Patterns of recurrent disease and survival. World J GastrointestPathophysiol 2018; 9(1): 8-17.

54. Hogan J, Samaha G, Burke J, Chang KH, Condon E, Waldron D, et al. Emergency Presenting Colon Cancer Is an Independent Predictor of Adverse Disease-Free Survival. Int Surg. 2015;100(1): 77-86.

55. Poornakala S, Prema NS. A study of morphological prognostic factors in colorectal cancer and survival analysis. Indian Journal of Pathology and Microbiology. 2019;62(1):36-42 